\title{
The Transmogrification of Teacher Education
}

If asked to name the largest teacher education programs in America, most of us would probably mention a research institution with a large student body, such as University of Texas at Austin, Ohio State University, University of Minnesota, University of Florida, or Arizona State University. In actuality, these universities have the five largest enrollments in the country (U.S. Department of Education, 2004, p. 276). Despite their size, none of these universities (nor any of the largest 50 institutions) can touch the enrollments of the five largest graduate programs in education in the nation-University of Phoenix, National University, Walden University, Nova Southeastern University, and Capella University (U.S. World and News Report, 2005 , p. 59) who have a combined enrollment of 40,000 or so students. The commonality among these five institutions, of course, is that they are all Internetbased, independent, and highly profitable.

Over the past ten years, I have had a vague notion that teacher education was being transformed by a number of trends-the streamlining of undergraduate degree programs, a strong emphasis on testing, the surge in alternative certification, and the proliferation of distance-education degree programs. To assess the status of teacher education in the early $21^{\text {st }}$ century, I reviewed data on programs from the more than 1,000 institutions and NUCPs (Non-University Certification Programs) that certify teachers in the United States.

However, examining the gritty details of certification across the broad spectrum of grade levels-from kindergarten to high school-and subject areas-from physical education to physics-across states and institutions seemed unwieldy. After some consideration, I decided to use English Education as an exemplar of changes in teacher certification. I reasoned that, unlike mathematics, science, bilingual education, and special education, English Education is not a "high needs" certification area, thus there would seem to be less urgency for alternative or emergency certifications in English. Using this logic, I surmised that trends in English Education might be comparable to developments in Social Studies Education, but would probably understate the situations in science, mathematics, bilingual and special education.

\section{Disparities in Teacher Certification among States}

According to Sections 207 and 208 of the Higher Education Act, states must report annually on the performance of candidates in teacher preparation programs in institutions within its borders. This information has been made public in an online database at www.title2.org.

Many state departments of education have responded to the new requirements of the Higher Education Act by assessing teacher competence in three areas: basic skills, professional practice, and knowledge of English content. Some states have mandated tests in all three areas; other states only test in one or two areas. Maine and Nebraska require only a basic skills test; Montana and lowa require no exams at all. States have the authority to determine how teacher performance is assessed. 
All states who test prospective teachers, except Florida and Michigan (who administer and score their own exams), outsource the assessments. Educational Testing Services (ETS) is the most popular provider of tests (the PRAXIS series), though some states use National Evaluation Services (NES). Table 1 provides the information on teacher testing in the content areas for each state. A blank means that the state does not require a test to demonstrate competence in the area. Cutoff scores for English content are given to show the disparities in requirements among the states-from a low of 142 on PRAXIS II in Washington D.C. to a high of 172 on PRAXIS II in Connecticut.

Table 1: Certification Requirements for Secondary English by State

\begin{tabular}{|c|c|c|c|}
\hline Institution & $\begin{array}{c}\text { Basic Skills Exam } \\
\text { Administrator (if PPST- } \\
\text { Passing Scores for } \\
\text { Reading/Writing/ } \\
\text { Mathematics) }\end{array}$ & $\begin{array}{l}\text { Professional Practice } \\
\text { Exam } \\
\text { Administrator, and } \\
\text { Passing Score }\end{array}$ & $\begin{array}{l}\text { English Content Area } \\
\text { Exam } \\
\text { Administrator, and } \\
\text { Passing Score }\end{array}$ \\
\hline Alabama & $\begin{array}{l}\text { APTTP (Alabama } \\
\text { Prospective Teacher } \\
\text { Training Program) } \\
\text { Applied Mathematics, } \\
\text { Reading for Information, } \\
\text { and Writing } \\
\text { assessments from the } \\
\text { ACT WorkKeys System }\end{array}$ & & $\begin{array}{l}\text { ETS } \\
\text { PRAXIS II } \\
10041=151\end{array}$ \\
\hline Alaska & $\begin{array}{l}\text { ETS } \\
\text { PPST }=175 / 174 / 173\end{array}$ & & $\begin{array}{l}\text { ETS } \\
\text { Not required, unless } \\
\text { adding additional } \\
\text { teaching area, then } \\
\text { PRAXIS II English tests } \\
10041=158, \\
20042=160\end{array}$ \\
\hline Arizona & & $\begin{array}{l}\text { NES } \\
\text { AEPA (Arizona Educator } \\
\text { Proficiency } \\
\text { Assessment,), waived } \\
\text { for teachers with three } \\
\text { or more years of } \\
\text { experience }\end{array}$ & $\begin{array}{l}\text { NES } \\
\text { English Content area } \\
\text { exam, Passing=240 } \\
\text { (Range=100-300). } \\
\text { Working on a } \\
\text { performance exam for } \\
\text { a permanent license. }\end{array}$ \\
\hline Arkansas & $\begin{array}{l}\text { ETS } \\
\text { PPST }=172 / 173 / 171\end{array}$ & $\begin{array}{l}\text { ETS } \\
\text { PLT 30524=164 }\end{array}$ & $\begin{array}{l}\text { ETS } \\
\text { PRAXIS II tests } \\
10042=159 \\
20042=150 \\
30043=145\end{array}$ \\
\hline California & $\begin{array}{l}\text { NES } \\
\text { Pass CBEST (California } \\
\text { Basic Education Skills } \\
\text { Test) }\end{array}$ & & $\begin{array}{l}\text { NES } \\
\text { CSET (California } \\
\text { Subject Exam for } \\
\text { Teachers, replacing } \\
\text { PRAXIS II as of } \\
2005)=240\end{array}$ \\
\hline Colorado & & & $\begin{array}{l}\text { ETS } \\
\text { PRAXIS II test } \\
\text { 10041=162 OR NES } \\
\text { PLACE (NES) } \\
\end{array}$ \\
\hline
\end{tabular}




\begin{tabular}{|c|c|c|c|}
\hline Connecticut & $\begin{array}{l}\text { ETS } \\
\text { PPST }=172 / 171 / 171\end{array}$ & & $\begin{array}{l}\text { ETS } \\
\text { PRAXIS II tests } \\
10041=172 \\
20042=160\end{array}$ \\
\hline Delaware & $\begin{array}{l}\text { ETS } \\
\text { PPST }=175 / 173 / 174\end{array}$ & & $\begin{array}{l}\text { ETS } \\
\text { PRAXIS II test } \\
10041=159\end{array}$ \\
\hline District of Columbia & $\begin{array}{l}\text { ETS } \\
\text { PPST }=172 / 171 / 174\end{array}$ & & $\begin{array}{l}\text { ETS } \\
\text { PRAXIS II test } \\
10041=142 \\
30043=150\end{array}$ \\
\hline Florida & $\begin{array}{l}\text { State of Florida } \\
\text { General Knowledge Test } \\
\text { (GK) }\end{array}$ & $\begin{array}{l}\text { State of Florida } \\
\text { Test PEd: (Professional } \\
\text { Education) }\end{array}$ & $\begin{array}{l}\text { State of Florida } \\
\text { SAE (Subject Area } \\
\text { Exam) in English for } \\
\text { grades } 6-12\end{array}$ \\
\hline Georgia & $\begin{array}{l}\text { ETS } \\
\text { PPST }=176 / 176 / 174 \\
\text { (waived with SAT>1000) }\end{array}$ & & $\begin{array}{l}\text { ETS } \\
\text { PRAXIS II tests } \\
10041=168 \\
20042=155\end{array}$ \\
\hline Hawaii & $\begin{array}{l}\text { ETS } \\
\text { PPST }=172 / 171 / 173\end{array}$ & & $\begin{array}{l}\text { ETS } \\
\text { PRAXIS II tests } \\
10041=164 \\
30043=150 \\
\end{array}$ \\
\hline Idaho & & & $\begin{array}{l}\text { ETS } \\
\text { PRAXIS II test } \\
10041=158\end{array}$ \\
\hline Illinois & $\begin{array}{l}\text { NES } \\
\text { ICTS Basic Skills test } \\
\text { (Illinois Certification } \\
\text { Testing System) }\end{array}$ & $\begin{array}{l}\text { NES } \\
\text { ICTS APT (Assessment } \\
\text { of Professional } \\
\text { Teaching) }=240\end{array}$ & $\begin{array}{l}\text { NES } \\
\text { ICTS English content } \\
\text { exam, grades } 9 \text { - } \\
12=240\end{array}$ \\
\hline Indiana & $\begin{array}{l}\text { ETS } \\
\text { PPST }=176 / 172 / 175\end{array}$ & & $\begin{array}{l}\text { ETS } \\
\text { PRAXIS II test } \\
10041=153\end{array}$ \\
\hline \multicolumn{4}{|l|}{ Iowa } \\
\hline Kansas & & $\begin{array}{l}\text { ETS } \\
\text { PLT } 30524=161\end{array}$ & $\begin{array}{l}\text { ETS } \\
\text { PRAXIS II test } \\
10041=\text { required, but } \\
\text { passing score yet to be } \\
\text { determined }\end{array}$ \\
\hline Kentucky & $\begin{array}{l}\text { ETS } \\
\text { PPST=Minimum passing } \\
\text { scores set by } \\
\text { institutions }\end{array}$ & $\begin{array}{l}\text { ETS } \\
\text { PLT } 30524=161\end{array}$ & $\begin{array}{l}\text { ETS } \\
\text { PRAXIS II tests } \\
10041=160 \\
20042=155\end{array}$ \\
\hline Louisiana & $\begin{array}{l}\text { ETS } \\
\text { PPST }=172 / 171 / 170\end{array}$ & $\begin{array}{l}\text { ETS } \\
\text { PLT } 30524=161\end{array}$ & $\begin{array}{l}\text { ETS } \\
\text { PRAXIS II tests } \\
10041=160 \\
30043=130\end{array}$ \\
\hline Maine & $\begin{array}{l}\text { ETS } \\
\text { PPST }=176 / 175 / 175\end{array}$ & & \\
\hline Maryland & $\begin{array}{l}\text { ETS } \\
\text { PPST }=177 / 173 / 177\end{array}$ & & $\begin{array}{l}\text { ETS } \\
\text { PRAXIS II tests } \\
10041=164 \\
30043=155 \\
\end{array}$ \\
\hline Massachusetts & NES & & NES \\
\hline
\end{tabular}




\begin{tabular}{|c|c|c|c|}
\hline & $\begin{array}{l}\text { Communication and } \\
\text { Literacy Skills }\end{array}$ & & $\begin{array}{l}\text { Subject Test in } \\
\text { Secondary } \\
\text { English }=240\end{array}$ \\
\hline Michigan & $\begin{array}{l}\text { NES } \\
\text { Basic skills }\end{array}$ & & $\begin{array}{l}\text { NES } \\
\text { Secondary English } \\
\text { MTTC (Michigan Test } \\
\text { for Teacher } \\
\text { Certification) }=240\end{array}$ \\
\hline Minnesota & $\begin{array}{l}\text { ETS } \\
\text { PPST }=173 / 172 / 171\end{array}$ & $\begin{array}{l}\text { ETS } \\
\text { PLT } 30524=153\end{array}$ & $\begin{array}{l}\text { ETS } \\
\text { PRAXIS II test } \\
10041=148 \\
\text { (certification in } \\
\text { Communication Arts \& } \\
\text { Lit, grades 5-12) }\end{array}$ \\
\hline Mississippi & $\begin{array}{l}\text { ETS } \\
\text { PPST }=170 / 172 / 169\end{array}$ & $\begin{array}{l}\text { ETS } \\
\text { PLT } 30524=152\end{array}$ & $\begin{array}{l}\text { ETS } \\
\text { PRAXIS II test } \\
10041=157\end{array}$ \\
\hline Missouri & & & $\begin{array}{l}\text { ETS } \\
\text { PRAXIS II test } \\
10041=158 \text { (English, } \\
\text { grades 9-12) }\end{array}$ \\
\hline \multicolumn{4}{|l|}{ Montana } \\
\hline Nebraska & $\begin{array}{l}\text { ETS } \\
\text { PPST }=170 / 172 / 171\end{array}$ & $\begin{array}{l}\text { State of Nebraska: } \\
\text { Human relations } \\
\text { training, special } \\
\text { education } \\
\text { competencies }\end{array}$ & \\
\hline Nevada & $\begin{array}{l}\text { ETS } \\
\text { PPST }=174 / 172 / 172\end{array}$ & $\begin{array}{l}\text { ETS } \\
\text { PLT } 30524=161\end{array}$ & $\begin{array}{l}\text { ETS } \\
\text { PRAXIS II tests } \\
10041=150 \\
30043=140\end{array}$ \\
\hline New Hampshire & $\begin{array}{l}\text { ETS } \\
\text { PPST }=174 / 172 / 172\end{array}$ & & $\begin{array}{l}\text { ETS } \\
\text { PRAXIS II tests } \\
10041=164 \\
20042=155\end{array}$ \\
\hline New Jersey & & & $\begin{array}{l}\text { ETS } \\
\text { PRAXIS II test } \\
10041=162\end{array}$ \\
\hline New Mexico & $\begin{array}{l}\text { NES } \\
\text { NMTA Basic skills (New } \\
\text { Mexico Teacher } \\
\text { Assessment) }\end{array}$ & $\begin{array}{l}\text { NES } \\
\text { NMTA Teacher } \\
\text { competency }=240\end{array}$ & $\begin{array}{l}\text { NES } \\
\text { NMTA English Content } \\
\text { Area }=240\end{array}$ \\
\hline New York & $\begin{array}{l}\text { NES } \\
\text { Liberal Arts and } \\
\text { Sciences Test } \\
(\text { LAST })=220\end{array}$ & $\begin{array}{l}\text { NES } \\
\text { Assessment of } \\
\text { Teaching Skills } \\
\text { (secondary)-Written } \\
(\text { ATS-W) }=220\end{array}$ & $\begin{array}{l}\text { NES } \\
\text { Content Specialty Test } \\
\text { (CST) in English }=220\end{array}$ \\
\hline North Carolina & $\begin{array}{l}\text { ETS } \\
\text { PPST }=176 / 173 / 173\end{array}$ & & $\begin{array}{l}\text { ETS } \\
\text { PRAXIS II tests } \\
10041+30043=321 \\
\text { combined score } \\
\end{array}$ \\
\hline North Dakota & $\begin{array}{l}\text { ETS } \\
\text { PPST }=173 / 173 / 170\end{array}$ & & $\begin{array}{l}\text { ETS } \\
\text { PRAXIS II test } \\
10041=151 \\
\end{array}$ \\
\hline Ohio & ETS & ETS & ETS \\
\hline
\end{tabular}




\begin{tabular}{|c|c|c|c|}
\hline & PPST $=173 / 172 / 172$ & PLT 30524=165 & $\begin{array}{l}\text { PRAXIS II test } \\
10041=167\end{array}$ \\
\hline Oklahoma & $\begin{array}{l}\text { ETS } \\
\text { PPST=173/172/171 }\end{array}$ & $\begin{array}{l}\text { NES } \\
\text { OGET (Oklahoma } \\
\text { General Education } \\
\text { Test) }=240\end{array}$ & $\begin{array}{l}\text { NES } \\
\text { OSAT (Oklahoma } \\
\text { subject Area Tests) in } \\
\text { English } 6-12=240\end{array}$ \\
\hline Oregon & $\begin{array}{l}\text { ETS } \\
\text { PPST }=174 / 172 / 175\end{array}$ & & $\begin{array}{l}\text { ETS } \\
\text { PRAXIS II tests } \\
10041=159 \\
20042=145\end{array}$ \\
\hline Pennsylvania & $\begin{array}{l}\text { ETS } \\
\text { PPST }=172 / 173 / 173\end{array}$ & & $\begin{array}{l}\text { ETS } \\
\text { PRAXIS II test } \\
10041=160\end{array}$ \\
\hline Rhode Island & & $\begin{array}{l}\text { ETS } \\
\text { PLT 30524=167 (will } \\
\text { allow job review in lieu } \\
\text { of passing score) }\end{array}$ & \\
\hline South Carolina & $\begin{array}{l}\text { ETS } \\
\text { PPST }=175 / 173 / 172\end{array}$ & $\begin{array}{l}\text { ETS } \\
\text { PLT 30524=165 }\end{array}$ & $\begin{array}{l}\text { ETS } \\
\text { PRAXIS II tests } \\
10041=162 \\
20042=150 \\
\end{array}$ \\
\hline South Dakota & & $\begin{array}{l}\text { ETS } \\
\text { PLT 30524=146 }\end{array}$ & $\begin{array}{l}\text { ETS } \\
\text { PRAXIS II test } \\
10041=154\end{array}$ \\
\hline Tennessee & $\begin{array}{l}\text { ETS } \\
\text { PPST }=174 / 173 / 173\end{array}$ & $\begin{array}{l}\text { ETS } \\
\text { PLT 30524=159 }\end{array}$ & $\begin{array}{l}\text { ETS } \\
\text { PRAXIS II tests } \\
10041=157 \\
30043=145 \\
\end{array}$ \\
\hline Texas & & $\begin{array}{l}\text { NES } \\
\text { TEXES (Texas } \\
\text { Exminations of } \\
\text { Educator } \\
\text { Standards) }=240\end{array}$ & $\begin{array}{l}\text { NES } \\
\text { English Language Arts } \\
\text { \& Reading } 8-12=240\end{array}$ \\
\hline Utah & & $\begin{array}{l}\text { ETS } \\
\text { PLT } 30524=160\end{array}$ & $\begin{array}{l}\text { ETS } \\
\text { PRAXIS II test } \\
10041=? \\
20042=? \\
30043=? \\
\text { Required, but passing } \\
\text { scores yet to be } \\
\text { determined }\end{array}$ \\
\hline Vermont & $\begin{array}{l}\text { ETS } \\
\text { PPST required, but no } \\
\text { minimum established }\end{array}$ & & $\begin{array}{l}\text { ETS } \\
\text { PRAXIS II test } \\
10041=172 \text { OR } \\
20042=160\end{array}$ \\
\hline Virginia & $\begin{array}{l}\text { ETS } \\
\text { PPST }=178 / 176 / 178\end{array}$ & & $\begin{array}{l}\text { ETS } \\
\text { PRAXIS II test } \\
10041=172\end{array}$ \\
\hline Washington & $\begin{array}{l}\text { WEST-B }(N E S)=240, \text { OR } \\
\text { PPST } \\
(\text { ETS })=177 / 174 / 176 \\
\text { OR CBEST=123 } \\
\text { composite }\end{array}$ & Included in PRAXIS II & $\begin{array}{l}\text { ETS } \\
\text { PRAXIS II test } \\
\text { 10041=158 (specially } \\
\text { designed for WA) }\end{array}$ \\
\hline West Virginia & $\begin{array}{l}\text { ETS } \\
\text { PPST }=174 / 172 / 172\end{array}$ & $\begin{array}{l}\text { ETS } \\
\text { PLT } 30524=156\end{array}$ & $\begin{array}{l}\text { ETS } \\
\text { PRAXIS II test } \\
10041=155 \text { (English }\end{array}$ \\
\hline
\end{tabular}




\begin{tabular}{|c|c|c|c|}
\hline & & & $5^{\text {th }}$ grade to adult) \\
\hline Wisconsin & $\begin{array}{l}\text { ETS } \\
\text { PPST }=175 / 174 / 173\end{array}$ & & $\begin{array}{l}\text { ETS } \\
\text { PRAXIS II test } \\
10041=160 \text { (broad- } \\
\text { field language arts, } \\
\text { English lit, comp. } \\
\text { journalism, speech, } \\
\text { ages 10-21) }\end{array}$ \\
\hline Wyoming & & $\begin{array}{l}\text { ETS } \\
\text { PLT 30524=? (passing } \\
\text { score to be } \\
\text { determined) }\end{array}$ & $\begin{array}{l}\text { ETS } \\
\text { PRAXIS II test } \\
\text { 10041=Required, but } \\
\text { passing score yet to be } \\
\text { determined }\end{array}$ \\
\hline
\end{tabular}

Unfortunately, some states require that institutions post only the total number of graduates in their Title Two reports, making it difficult to ascertain the number of newly certified teachers by subject area and grade level. Likewise, many states report teachers certified through alternative programs in aggregate. Thus, in some states, determining the precise number of teachers in a subject area who have been certified through traditional and alternative programs requires persistence and a great deal of footwork.

When I could not find data in reports in the Title Two database, I obtained information from state departments of education and individual institutions. Some figures were gleaned from institutions' NCATE reports. Using these resources, I identified the fifteen largest English Education programs in the country and examined the requirements and unique attributes of each program. Next, I compared the number of English teachers going through NUCPs against those going through programs at selected doctoral institutions located in the same state. Finally, I analyzed teacher education programs in the ten "best" liberal arts institutions, at least according to U.S. News and World Report (2005).

\section{The Largest Programs}

In 2004, the largest group of teachers of English did not matriculate at a university at all, but received their teaching credentials from K-12 school districts. The two largest preparation programs in English Education are Non-University Certification Programs (NUCPS) in California and Texas (U.S. Department of Education, 2005). The growth of NUCPs in these two populous states is indicative of a nationwide trend to streamline certification requirements and open entry to the profession. In Texas and California, the education, training, and assessment of alternatively certified English teachers are wholly the responsibility of K-12 personnel.

The third largest producer of English teachers is National University, an institution with a small, non-virtual campus in La Jolla, and a huge graduate program that is delivered over the Internet (they have the largest graduate program in education in the country behind University of Phoenix).

The fourth largest English Education program is the NUCP in New Jersey. As in California and Texas, New Jersey's NUCP offers a "learn while you earn" plan that enables holders of a bachelor's degree to teach right away. New Jersey operates its NUCP through community colleges, whose instructors also teach the classes. 
According to New Jersey's recruiting brochure, “The Alternate Route is different in that the preparation for teaching is done while on the job rather than prior to entering a classroom" [sic] (New Jersey City University, 2005). Perhaps George Orwell would appreciate the effort to redefine the meaning of preparation.

The fifteen largest English Education programs in the U.S.A. in 2004 are listed in Table 2 as follows:

Table2: The Fifteen Largest English Education Programs in the U.S.A., 2004

\begin{tabular}{|l|l|l|}
\hline \multicolumn{1}{|c|}{ Rank } & \multicolumn{1}{|c|}{ Institution or Agency } & \multicolumn{1}{c|}{$\begin{array}{c}\text { Number of } \\
\text { English teachers }\end{array}$} \\
\hline 1 & California NUCP & 168 \\
\hline 1 & Texas NUCP & 168 \\
\hline 3 & National University (California) & 146 \\
\hline 5 & New Jersey NUCP & 101 \\
\hline 6 & Western Michigan University & 101 \\
\hline 7 & Wayne State University (Michigan) & 93 \\
\hline 8 & Eastern Michigan University & 92 \\
\hline 9 & Central Michigan University & 80 \\
\hline 10 & Chapman University (California) & 79 \\
\hline 11 & Georgia NUCP & 75 \\
\hline 12 & University of North Texas & 58 \\
\hline 13 & Saginaw State University (Michigan) & 55 \\
\hline 14 & Grand Valley State University (Michigan) & 54 \\
\hline 15 & Kent State University & 52 \\
\hline
\end{tabular}

(“NUCP"=Non-University Certification Program)

Obviously, the career paths to becoming a teacher of English have expanded dramatically with the proliferation of NUCPs and the phenomenon of credentials deliverable over the Internet. Today, prospective teachers may choose from among five very different kinds of programs:

1. "Learn while you earn" NUCPs administered by school districts or other agencies,

2. Internet or hybrid programs (Internet-based programs supplemented by one or more real-time, in-class sessions) administered by for-profit enterprises or universities,

3. Preparation programs at baccalaureate liberal arts colleges,

4. Preparation programs at regional, master's level institutions,

5. Preparation programs at doctoral institutions.

Of the 15 largest programs in English Education, five are "learn while you earn" NUCPs (California, Texas, New Jersey, Georgia, Colorado); three deliver Internet or hybrid degrees (National University, Chapman University, University of North Texas); five are traditional, master's level institutions (four from Michigan-Eastern Michigan, Central Michigan, Saginaw State, Grand Valley State-and one from OhioKent State); and two are doctoral institutions (Wayne State and Western Michigan University). No English Education program in the top 15 is located within a liberal arts college. 
The over-representation of schools from Michigan is largely due to the extended reach of state-supported institutions in Michigan. Western Michigan University has eight branch campuses-in Battle Creek, Grand Rapids, Holland, Lansing, Muskegon, South Haven, Benton Harbor, and Traverse City. Wayne State has six satellite campuses in the Detroit area. Eastern Michigan University delivers post-baccalaureate initial teacher certification programs in several locations in Detroit and Flint and also has a large distance education program. Central Michigan University operates off-campus programs to more than 8,000 students in more than 60 locations throughout the United States, Canada, and Mexico-about 1\% of whom seek to teach secondary English. Saginaw State University has a graduate center in Macomb County, Michigan, which offers four different graduate programs in education, including an Accelerated Certification Education (ACE). Grand Valley State has four branch campuses scattered throughout the state.

Perhaps surprisingly, no institutions in the top fifteen are from New York or Florida. The largest English Education program in Florida is at University of South Florida, where 45 students graduated in 2003-2004; the NUCPs in Florida handed out temporary certificates to more than 289 students, 39 of whom are going to teach English. In Florida, a recent law requires every school district in the state to develop an "in-house" alternative teacher preparation program. The alternative certification program requires prospective teachers to take a brief, "crash course in survival skills," then they begin teaching immediately. Again, the training, supervision, and assessment of these teachers are at the sole discretion of the school district. No collaboration with a university is necessary.

\section{Distinguishing Features of Programs}

To get a sense of the kinds of experiences offered via the five career tracks in English Education, Table 3 (below) compares the programs of four of the largest programs in America: the Los Angeles United School District (part of California's massive NUCP network), National University (via the Internet), Eastern Michigan University (a master's level university), and Wayne State University (a doctoral institution).

Table 3: Comparison of Types of Programs in English Education

\begin{tabular}{|c|c|c|c|c|c|}
\hline $\begin{array}{l}\text { Granting } \\
\text { Agency, } \\
\text { (Carnegie } \\
\text { Classification) }\end{array}$ & Requirements & $\begin{array}{l}\text { Semester } \\
\text { hours in } \\
\text { English } \\
\text { Education }\end{array}$ & $\begin{array}{l}\text { Semester } \\
\text { hours in } \\
\text { teaching } \\
\text { reading }\end{array}$ & $\begin{array}{l}\text { Required } \\
\text { Field } \\
\text { experience } \\
\text { before } \\
\text { teaching }\end{array}$ & $\begin{array}{l}\text { Student } \\
\text { Teaching }\end{array}$ \\
\hline $\begin{array}{l}\text { California } \\
\text { NUCP, Los } \\
\text { Angeles United } \\
\text { School District } \\
\text { (Internet- } \\
\text { based) }\end{array}$ & $\begin{array}{l}\text { Bachelor's } \\
\text { degree, must } \\
\text { pass California } \\
\text { Basic } \\
\text { Educational } \\
\text { Skills Test, } \\
\text { state test for } \\
\text { single } \\
\text { endorsement } \\
\text { in English. }\end{array}$ & 3 (Internet) & 3 (Internet) & No & No \\
\hline $\begin{array}{l}\text { National } \\
\text { University }\end{array}$ & $\begin{array}{l}\text { Bachelor's } \\
\text { degree. }\end{array}$ & 0 & 0 & $\begin{array}{l}\text { Yes, though } \\
\text { not }\end{array}$ & $\begin{array}{l}\text { Yes, though } \\
\text { "Summer }\end{array}$ \\
\hline
\end{tabular}




\begin{tabular}{|c|c|c|c|c|c|}
\hline $\begin{array}{l}\text { (Internet-based } \\
\text { master's } \\
\text { degree) }\end{array}$ & $\begin{array}{l}\text { Entrance test } \\
\text { only required } \\
\text { with grade } \\
\text { point of less } \\
\text { than } 2.5, \text { must } \\
\text { pass California } \\
\text { Basic } \\
\text { Educational } \\
\text { Skills Test; } \\
\text { must pass } \\
\text { state test for } \\
\text { single } \\
\text { endorsement } \\
\text { in English. }\end{array}$ & & & $\begin{array}{l}\text { explicated in } \\
\text { the catalog }\end{array}$ & $\begin{array}{l}\text { school, after } \\
\text { school } \\
\text { programs, and } \\
\text { outdoor } \\
\text { education } \\
\text { programs" } \\
\text { may be } \\
\text { substituted for } \\
\text { student } \\
\text { teaching } \\
\text { (National } \\
\text { University } \\
\text { 2005). }\end{array}$ \\
\hline $\begin{array}{l}\text { Eastern } \\
\text { Michigan } \\
\text { University } \\
\text { (Master's } \\
\text { University I) }\end{array}$ & $\begin{array}{l}\text { Moderately } \\
\text { selective } \\
\text { (average } \\
\text { ACT=20), Must } \\
\text { pass Michigan } \\
\text { State Basic } \\
\text { Skills Test. }\end{array}$ & 3 hours & 3 hours & $\begin{array}{l}\text { Significant } \\
\text { (more than } \\
200 \text { hours } \\
\text { spent in } \\
\text { schools) }\end{array}$ & $\begin{array}{l}\text { Yes, full } \\
\text { semester }\end{array}$ \\
\hline $\begin{array}{l}\text { Wayne State } \\
\text { University } \\
\text { (Research } \\
\text { University } \\
\text { Extensive) }\end{array}$ & $\begin{array}{l}\text { Moderately } \\
\text { selective } \\
\text { (average } \\
\text { ACT=20), must } \\
\text { pass Michigan } \\
\text { State Basic } \\
\text { Skills Test. }\end{array}$ & 15 hours & 3 hours & $\begin{array}{l}\text { Significant } \\
\text { (more than } \\
200 \text { hours } \\
\text { spent in } \\
\text { schools) }\end{array}$ & $\begin{array}{l}\text { Yes, full } \\
\text { semester }\end{array}$ \\
\hline
\end{tabular}

Of the programs in Table 3, the NUCP at Los Angeles United School District is the only one that does not require prospective teachers to spend time in schools as a prerequisite to full-time teaching. These untrained, inexperienced teachers are placed in classrooms under the power granted to schools by California's Senate Bill 57 , which "allows...people to become teachers by successfully completing tests and classroom observations in lieu of traditional teacher preparation course work and student teaching."

National University requires neither a course in reading nor a course in English methods, seemingly odd for a program leading to certification in English. At National, field experience and student teaching may include time spent at "summer school, after school programs, and outdoor education programs" (National University, 2005).

Eastern Michigan offers courses in English methods and reading. However, compared to the other four institutions, Wayne State's requirements seem almost expansive-five classes in English Education: Linguistics and Education, Young Adult Literature, Methods of Teaching English: Grades 7-12, Teaching Composition, and Teaching Literature; one class in reading-Reading in the Content Areas; significant hours in schools prior to student teaching; and a full semester for the student teaching experience.

Apparently, doctoral institutions educate a relatively small percentage of prospective English teachers. Even in Michigan, home to two of the largest English education programs in the nation (Western Michigan and Wayne State) and two prominent research universities (University of Michigan and Michigan State 
University), doctoral institutions prepare less than one-third of all new English teachers.

\section{Liberal Arts Colleges}

The English education programs of the "top ten" national liberal arts colleges (U.S. World and News Report, 2005) share a lack of focused preparation with NUCPS and Internet-based programs listed in Table 3. Table 4 depicts the nature of the programs of ten liberal arts colleges.

Table 4: Preparation in English Education at Liberal Arts Colleges

\begin{tabular}{|c|c|c|c|c|}
\hline $\begin{array}{l}\text { Granting } \\
\text { Agency, } \\
\text { (Carnegie } \\
\text { Classification) }\end{array}$ & $\begin{array}{l}\text { Semester } \\
\text { hours in } \\
\text { English } \\
\text { Education }\end{array}$ & $\begin{array}{l}\text { Semester } \\
\text { hours in } \\
\text { teaching } \\
\text { reading }\end{array}$ & $\begin{array}{l}\text { Required } \\
\text { Field } \\
\text { experience } \\
\text { before } \\
\text { teaching } \\
\end{array}$ & $\begin{array}{l}\text { Student } \\
\text { Teaching }\end{array}$ \\
\hline $\begin{array}{l}\text { Williams College } \\
\text { (Baccalaureate } \\
\text { College, } \\
\text { Liberal Arts) } \\
\end{array}$ & 0 & 3 hours & $\begin{array}{l}\text { Minimal } \\
\text { (total of } 30 \\
\text { hours spent } \\
\text { in a school) } \\
\end{array}$ & $\begin{array}{l}\text { Yes (administered by the } \\
\text { Massachusetts College of } \\
\text { Liberal Arts). }\end{array}$ \\
\hline $\begin{array}{l}\text { Amherst College } \\
\text { (with Mount } \\
\text { Holyoke) }\end{array}$ & 0 & 0 & $\begin{array}{l}5 \text { courses } \\
\text { that require } \\
\text { some field } \\
\text { experience }\end{array}$ & $\begin{array}{l}\text { Yes, 14-credit hour student } \\
\text { teaching in spring }\end{array}$ \\
\hline $\begin{array}{l}\text { Swarthmore } \\
\text { College }\end{array}$ & 0 & 0 & no & $\begin{array}{l}\text { Students teach for } 12 \text { weeks, } \\
\text { visited once per week by } \\
\text { supervisor }\end{array}$ \\
\hline Wellesley College & 0 & 0 & $\begin{array}{l}\text { One field } \\
\text { course } \\
\text { required } \\
\text { prior to } \\
\text { student } \\
\text { teaching }\end{array}$ & Students teach for 12 weeks \\
\hline Carleton College & $\begin{array}{l}\text { Mentions } \\
\text { possible } \\
\text { subject } \\
\text { emphasis } \\
\text { in catalog }\end{array}$ & 0 & $\begin{array}{l}\text { Minimal, } \\
\text { negotiated } \\
\text { with } \\
\text { instructor }\end{array}$ & $\begin{array}{l}10 \text { weeks } \\
\text { Recommends students take } \\
\text { "thirteenth term" so they can } \\
\text { student teach-at a greatly } \\
\text { reduced rate of tuition }\end{array}$ \\
\hline Pomona College & 0 & 0 & $\begin{array}{l}\text { Minimal, } 25 \\
\text { hours total }\end{array}$ & $\begin{array}{l}10 \text { weeks } \\
\text { In collaboration with } \\
\text { Claremont Graduate School }\end{array}$ \\
\hline Bowdoin College & $\begin{array}{l}0 \text { (but one } \\
\text { course in } \\
\text { teaching } \\
\text { writing) }\end{array}$ & 0 & 0 & 10-12 weeks \\
\hline Davidson College & 0 & 0 & $\begin{array}{l}\text { Some } \\
\text { tutoring }\end{array}$ & 10-12 weeks \\
\hline Haverford College & 0 & 0 & $\begin{array}{l}\text { Weekly visits } \\
\text { to a } \\
\text { classroom, } \\
\text { weekly } \\
\text { exchange of } \\
\text { letters }\end{array}$ & 12 weeks \\
\hline Wesleyan College & -- & -- & - & $\begin{array}{l}\text { Teacher education phased } \\
\text { out in } 1996\end{array}$ \\
\hline
\end{tabular}


Because the numbers of students seeking teacher certification at liberal arts colleges are small, students from all subject areas are usually combined into a single class for curriculum, methods, and other education courses. It is not unusual for a professor of a methods course in a liberal arts college to have students majoring in music, physical education, science, mathematics, social studies, and health sitting alongside majors in English. Of the ten liberal arts colleges surveyed, one mentioned a course specific to the content area (Carlton); one required a reading course (Williams).

\section{The State of the Profession}

Twenty years ago, few states had NUCPs and those that did dusted them off only in emergencies, such as an unexpected death or a temporary shortage of teachers caused by a sudden spike in population (in areas like Orlando or Las Vegas).

Today, NUCPs supply an increasing percentage of new teachers of English. In California, approximately one in five new teachers enter the profession through NUCPs; in Texas and New Jersey, one in four new teachers come from NUCPs (Feistritzer 2004). In Florida, where every school district in the state has the capability of certifying teachers, the numbers of students choosing NUCPs may expand rapidly. When comparing the number of English teachers who graduate from doctoral institutions with the number of students who take alternative routes via NUCPs, the difference is startling (U.S. Department of Education, 2005) as follows:

- NUCPs in California certified 168 English teachers; The University of California at Berkeley graduated 22; Stanford 11.

- NUCPs in Texas certified 168 English teachers; The University of Texas at Austin graduated 27.

- $\quad$ NUCPs in New Jersey certified 101; Rutgers University graduated 39.

- $\quad$ NUCPs in Georgia certified 75; The University of Georgia graduated 26.

- NUCPs in Colorado certified 51; The University of Colorado at Boulder graduated 36.

- NUCPs in Louisiana certified 22; L.S.U. graduated 14.

- NUCPs in Florida certified 39; Florida State graduated 23

As is evident from the burgeoning numbers of English teachers coming out of National University and Chapman University (together, the institutions produced 225 English teachers in 2004), Internet-based, virtual degrees in education, also have great appeal. They are fast, easy, and require limited face-to-face interactions. In point of fact, the largest English Education program in Arizona is a virtual one at The University of Phoenix which produced 36 English teachers in 2004; the University of Arizona graduated 21.

Some institutions of higher education, lured by the profitability of distance education, have added "100\% internet" degrees. For example, the second largest producer of English teachers in Texas is the program at The University of North Texas. North Texas offers a traditional on-campus, field-based undergraduate degree, but it 
also offers a one-year, accelerated, graduate program over the Internet. According to North Texas's website,

The Online Teacher Certification Program was designed for mature students who have a bachelor's degree and want to earn initial secondary teacher certification at the graduate level. The program consists of 12 graduate credit hours and a 3-6 hour mentored internship. Content for all four courses is delivered $100 \%$ online. (University of North Texas, 2005)

In a comprehensive study of alternative and traditional certification, Wenglinsky (2000) found that students who had teachers from university teacher preparation programs outperformed students who had teachers who were alternatively certified. More recently, Darling-Hammond, Holtzman, Gatlin, \& Vasquez-Heilig (2005) found that alternatively certified teachers actually have deleterious effects on student achievement.

Interestingly, the Darling-Hammond (et al.) study surveyed thousands of teachers from the Houston Independent School district over a period of six years. Houston I.S.D. happens to be one of the largest NUCPs in Texas. Using student achievement measures across six different tests, the researchers found that "uncertified teachers showed negative effects across all six tests...alternatively certified teachers had negative effects on achievement on five tests" (p. 19). Despite the evidence that student achievement suffers when their teachers hail from NUCPS and "fast-track" alternative programs, these programs are becoming dominant in many states.

\section{Conclusions}

Whether they acknowledge it or not, universities who prepare teachers are currently engaged in a fierce fight for students. Competition is coming from profitcentered enterprises and K-12 school districts-especially in urban areas. State legislators, anxious to cut costs in higher education, have allowed teacher certification to migrate from universities to school districts, community colleges, and apparently-any NUCP that promises to provide a fresh supply of warm bodies for the front lines of teaching on the cheap. At the same time, accrediting agencies such as NCATE (National Council for the Accreditation of Teacher Education) and TEAC (Teacher Education Accrediting Council) continue to ramp up rigor and accountability.

At a time when global competition is heating up, and American students' academic performance may be on the decline (Bauerlein 2005, Bureau of Labor Statistics 2005, National Endowment of the Arts 2004, U.S. Census Bureau 2005), the need for experienced, well-educated, enthusiastic teachers has never been greater. The justification for a quick and easy entry to teaching seems to be that anyone has a right to teach-even those who never learned how. Expecting a student with a liberal arts major and minimal experience working with children to waltz into a classroom and begin teaching effectively is not hopeful-it's idiotic. Yet, in half of the states of the union, an alternatively certified teacher is not required to bother with setting foot in a K-12 classroom prior to the first day of school.

A recent editorial in the New York Times reiterated the need for better reporting from institutions and higher standards for teachers: "At the very least, both 
the federal government and the states need better data systems to keep track of how many teachers are being trained.... The states must also bite the bullet and finally close any colleges of education that are no more than diploma mills" (2005).

Certainly, closing the diploma mills would be a good place to start. However, the demise of diploma mills seems unlikely, considering that a former lobbyist for the University of Phoenix has served as Assistant Secretary for Postsecondary Education for the past four years. Add the fact that Congress recently approved federal aid to institutions that provide 100\% of their degrees over the Internet and you begin to understand why the outlook for diploma mills has never been brighter.

\section{References}

Apsel, Deborah (2005 May 3). Special report: Teaching Fellows make their mark. Retrieved July 2, 2005 from http://www.insideschools.org/nv/NV teaching fellow may05.php.

Bauerlein, M. (2005, February 2). Reading at risk, culture at risk. Teachers College Record. Retrieved March 3, 2005 from http://www.tcrecord.org.

Bureau of Labor Statistics (2005, January 12). Time-use survey-First results announced by BLS. Washington, D.C.: Bureau of Labor Statistics.

Darling Hammond, L., Holtzman, D., Gatlin, S., \& Vasquez-Heilig, J. (2005). Does Teacher Preparation Matter? Menlo Park, CA: Stanford University.

Duncan-Poitier, Johanna (2004, October 18). Update on Alternative Teacher Preparation Programs, Memo to the Members of the Board of Regents.

Feistritzer, E. (2004). Alternative teacher certification: A state-by-state analysis. Washington, D.C.: The National Center for Education Information

National Endowment of the Arts (2004). Reading at risk: A survey of literary reading in America. Washington D.C.: NEA.

National University (2005). Student teaching requirements. Retreived May 10, 2005 from www.nu.edu/academics/schools SOE/TeacherEducation/Degrees/780364.html.

New Jersey City University (2005). New pathways to teaching in New Jersey: What is the alternate route in New Jersey? Retrieved May 11, 2005 from http://www.njcu.edu/academics/coe np whatis.asp.

New York City Schools (2005). About New York City Teaching Fellows. Retrieved July 19, 2005 from: http://www.nyctyf.org/about/history.html

New York State Education Department (2005a). Factsheet for alternative licensure. 
Retrieved July 15 from: www.Nycty.org/about/program faq.html

New York State Education Department (2005b). The Intensive (Transitional C)

Program. Retrieved July 10 from:

http://www.highered.nysed.gov/ocue/transitional\%20c.htm

New York Times (19 July, 2005). Failing to teach in high school. Editorial. p. A 24.

State University of New York at Cortland (2004). NCATE Institutional Report.

Cortland, New York.

University of North Texas (2005). Online teacher certification. Retrieved May 5, 2005 from:

http://www.coe.unt.edu/becoming a teacher/secondary/About.htm.

U.S. Department of the Census (2005). Statistical abstract of the United States: 2004-2005. Washington, D.C.: U.S. Government Printing Office.

U.S. Department of Education (2004). Digest of Education Statistics. Washington, D.C.: Government Printing Office.

U.S. Department of Education (2005). Title II State Report 2004. Retrieved July 20, 2005 from http://www.title2.org/.

U.S. World and News Report (2005). Ultimate College Guide. New York: Sourcebooks.

U.S. World and News Report (2005, October 17). Largest grad programs, p. 59.

Wenglinsky, H. (2000). Teaching the teachers. Princeton, NJ: ETS Research Division.

Wildavsky, B. (Ed.) (2005). Ultimate Guide to Becoming a Teacher. Naperville, Illinois: Sourcebooks. 